\title{
High Levels of Circulating Soluble Receptors for Tumor Necrosis Factor in Hairy Cell Leukemia and Type B Chronic Lymphocytic Leukemia
}

\author{
Werner Digel, Franz Porzsolt, Mathias Schmid, Friedhelm Herrmann, Werner Lesslauer, and Manfred Brockhaus \\ Department of Internal Medicine III, University of Ulm, D-0000 Ulm, Federal Republic of Germany; \\ Department of Internal Medicine I, University of Freiburg, D-7800 Freiburg, Federal Republic of Germany; \\ and Central Research Units, Hoffmann-La Roche, Basel, CH-4002 Switzerland
}

\begin{abstract}
The presence of soluble tumor necrosis factor (TNF) binding proteins (BP) was investigated in the sera of healthy volunteer blood donors and cancer patients. Two distinct types of TNFBP, types A and B, which are immunologically related to the cellular 75-kD TNF receptor (TNFR) and the cellular 55kD TNFR, respectively, were assessed by immunoassays using nonblocking anti-receptor antibodies and ${ }^{125}$ I-recombinant human TNF $\alpha$. As compared to the titers observed in 25 healthy controls, TNFBP types A and B titers were found to be elevated in almost all sera obtained from patients with underlying malignant disease. The highest amounts of TNFBP were seen in the sera of patients with $B$ cell malignancies including hairy cell leukemia (HCL) and type B chronic lymphocytic leukemia. Treatment of HCL patients with recombinant human interferon- $\alpha$ was associated with decrease of circulating TNFBP. ( $J$. Clin. Invest. 1992. 89:1690-1693.) Key words: B-cell malignancies - serum • interferon therapy • tumor necrosis factor binding protein
\end{abstract}

\section{Introduction}

Tumor necrosis factor (TNF) ${ }^{1}$ is a pleiotropic cytokine that plays a major role in inflammation and host defense to infection $(1,2)$. It exerts antitumor activity in vivo as demonstrated in certain transplanted mouse tumor models (for reviews, see references 1 and 3). In the context of other factors present, TNF acts as an antileukemic agent (4) or stimulates leukemia growth in patients with hairy cell leukemia (HCL), type B chronic lymphocytic leukemia (B-CLL) (5-7), and acute myelogenous leukemia (8-10).

Address reprint requests to Dr. F. Herrmann, Department of Internal Medicine I, University of Freiburg, Hugstetter Strasse 55, D-7800 Freiburg, Federal Republic of Germany.

Received for publication 6 August 1991 and in revised form 30 December 1991.

1. Abbreviations used in this paper: B-CLL, type B chronic lymphocytic leukemia; HCL, hairy cell leukemia; rh, recombinant human; TNF, tumor necrosis factor; TNFBP, TNF binding protein(s); TNFR, TNF receptor(s).

J. Clin. Invest.

(c) The American Society for Clinical Investigation, Inc.

$0021-9738 / 92 / 05 / 1690 / 04 \$ 2.00$

Volume 89, May 1992, 1690-1693
Recently, two distinct types of cellular TNF receptors (TNFR) have been identified by molecular cloning (11-13) and have been shown to be differentially expressed on various human cells (14). Non-cross-reactive monoclonal antibodies (MAb) have been prepared against both the 75-kD type A TNFR (utr MAb series) and the 55-kD type B TNFR (htr MAb series) (14), and it has been demonstrated that both types of TNFR share a high degree of amino acid sequence homology which is, however, restricted to the extracellular domain of the molecules (15). Human urine and serum contain a TNF inhibitory activity. Molecular cloning identified this molecule as soluble fragments of both TNFR $(16,17)$. In the following we refer to these soluble fragments of TNFR as TNF binding proteins (TNFBP) types A and B. In this article, we describe a sensitive assay to detect TNFBP in human serum collected from healthy subjects and patients with a variety of mostly hematopoietic malignancies. Circulating TNFBP levels were found increased in almost all patients' sera as compared to normal controls. Patients with HCL and B-CLL disclosed the highest TNFBP serum levels, particularly of the type $A$, that decreased during effective recombinant human interferon- $\alpha$ (rhIFN $\alpha$ ) therapy.

\section{Methods}

Patients. We studied sera from 167 patients with malignant disorders including hematopoietic neoplasias $(n=137)$ and other tumor types $(n$ $=30$ ). Sera from 25 healthy age-matched subjects served as controls. In selected experiments, sera collected from patients with HCL were also studied during therapy with rhIFN $\alpha$. All healthy controls and patients investigated were free of concomitant illness, particularly infectious disease. Informed consent was obtained in accordance with our institutional policy.

Serum samples. Blood obtained by venipuncture was allowed to clot at room temperature for $1 \mathrm{~h}$; after centrifugation the serum was stored in volumes of $\sim 0.5 \mathrm{ml}$ at $-70^{\circ} \mathrm{C}$ until used.

Antibodies. MAb raised against partially purified TNFR from HL60 cells (htr series) and U937 cells (utr series) were previously described (14). MAb htr-20 specifically binds to the p55 TNFR (type B) without inhibiting TNF binding (M. Brockhaus, unpublished data). Similarly, utr-4 is a noninhibitory antibody against the p75 TNFR (type A) (14).

TNFR assay. Sera were diluted 1:20 with a $1 \%$ solution of fat-free milk powder in $50 \mathrm{mM}$ Tris- $\mathrm{HCl}, \mathrm{pH} 7.4,5 \mathrm{mM}$ sodium EDTA, 140 $\mathrm{mM}$ sodium chloride, and $0.02 \%$ sodium azide (blocking buffer). 96 well polyvinyl microtiter plates (Dynatech Laboratories, Inc., Alexandria, VA) were sensitized with affinity-purified rabbit anti-mouse immunoglobulin $(10 \mu \mathrm{g} / \mathrm{ml})$ followed by overnight incubation with spent culture medium from the hybridomas htr- 20 or utr- 4 .

The wells were washed once with PBS and incubated for $3 \mathrm{~h}$ at $4^{\circ} \mathrm{C}$ with the diluted serum samples. After three washings with PBS the 
wells were incubated with radioiodinated $\mathrm{rhTNF} \alpha\left(50 \mu \mathrm{l}, 7 \times 10^{5} \mathrm{cpm} /\right.$ $\mathrm{ml}$, sp act $450 \mathrm{Ci} / \mathrm{mM}$ ) in blocking buffer for $2 \mathrm{~h}$ at $4^{\circ} \mathrm{C}$. The wells were washed four times with PBS and bound ${ }^{125}$ I-rhTNF $\alpha$ was determined by gamma scintillation counting.

The TNFBP concentration was expressed as picomole per liter ${ }^{125} \mathrm{I}$ rhTNF $\alpha$ binding capacity in serum. The background was not subtracted. Unspecific binding of ${ }^{125} \mathrm{I}$-rhTNF $\alpha$ in the presence of an excess of unlabeled competitor TNF $\alpha$ was $<40 \mathrm{pM}$. The assays were linear for TNFBP in the reported range (not shown). The addition of exogenous rhTNF $\alpha(10 \mathrm{ng} / \mathrm{ml})$ to the serum decreased the measured TNFBP concentration by $\sim 30 \%$ also in the samples with elevated TNFBP (data not shown).

Data analysis. Data are expressed as mean $\pm \mathrm{SE}$ if not otherwise indicated. Data analysis was performed with Tukey's studendized oneway analysis of variance with simultaneous comparisons of groups and $5 \%$ was chosen as level of significance.

\section{Results}

TNFBP in serum. Soluble TNFBP of both types A and B were detected at low concentrations ( $79 \pm 14$ and $61 \pm 12$ pM, respectively) in the sera of healthy individuals (Fig. 1). From these data a 100 pM TNF binding capacity was considered as the upper normal limit for both TNFBP. Under the assumption of a 1:1 molar stoichiometry of the TNF/TNFBP complex and an average molecular mass of $30 \mathrm{kD}$ for TNFBP, this cutoff is equivalent to a TNFBP concentration of $3 \mathrm{ng} / \mathrm{ml}$. Almost all sera from the disease groups contained concentrations of type A TNFBP (150 of 167 patients) and type B TNFBP (159 of 167 patients) above level of healthy controls, $P<0.0001$. The highest levels of TNFBP, predominantly of type A were detected in $\operatorname{HCL}(1,291 \pm 829 \mathrm{pM})$ and B-CLL patients $(576 \pm 603 \mathrm{pM})(\mathrm{Fig}$ 1). Statistical comparisons of groups showed a significant difference of type A TNFBP but not type B TNFBP between the HCL group and B-CLL patients as well as between both disease entities on the one hand and the other malignancies on the other hand $(P<0.05)$. All $33 \mathrm{HCL}$ patients investigated disclosed elevated TNFBP, although the concentration of TNFBP did, however, not clearly correlate with the disease stage according to the classification of Janssen and Hermans (18) in HCL or to the Rai classification (19) in CLL (data not shown).

Decrease of TNFBP during rhIFN $\alpha$ therapy. We also determined both forms of TNFBP in serum of six HCL patients during treatment with rhIFN $\alpha$. The serum levels of both TNFBP began to decrease several weeks after initiation of rhIFN $\alpha$ therapy (Fig. 2), and the decrease was most pronounced in patients presenting with very high type A TNFBP concentrations before treatment. At the time of TNFBP measurement during rhIFN $\alpha$ therapy the patients were all in complete (patients 2, 4, and 6) or partial (patients 1, 3, and 5) remission.

TNFBP type A decreased in all patients during therapy between 276 and $2,890 \mathrm{pM}$. In two patients with untreated stable
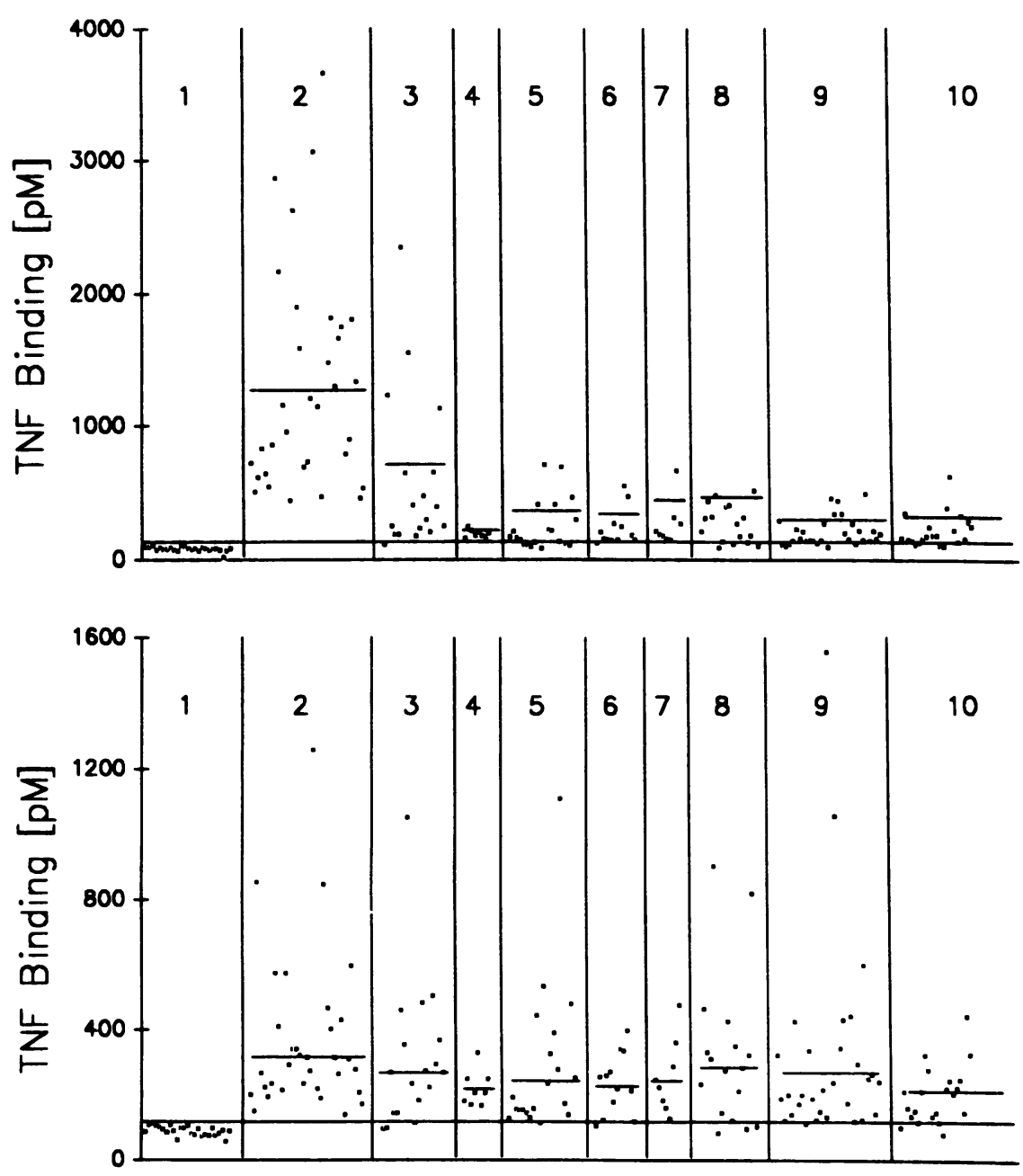

Figure 1. TNFBP in the serum of healthy individuals and patients with various malignancies $(1=$ normal controls, $2=\mathrm{HCL}, 3$ = B-type CLL, $4=$ multiple myeloma, 5 $=$ acute myelogenous leukemia, $6=$ non-Bcell acute lymphoblastic leukemia, $7=$ chronic myelogenous leukemia, 8 = myelodysplastic syndrome $9=$ solid tumors, $10=$ other hematologic diseases [Hodgkin's disease, T-cell-lymphoma]). Type A TNFBP was detected by using anti-TNFR MAb utr-4 (top) and type B TNFR by using anti-TNFR MAb htr-20 (bottom) and ${ }^{125}$ I-rhTNF as described in Methods. Bound ${ }^{125} \mathrm{I}-\mathrm{rhTNF}$ is expressed as TNF binding capacity in picomoles of TNF per liter of serum. The horizontal lines indicate the mean values. The data points represent single determinations. 

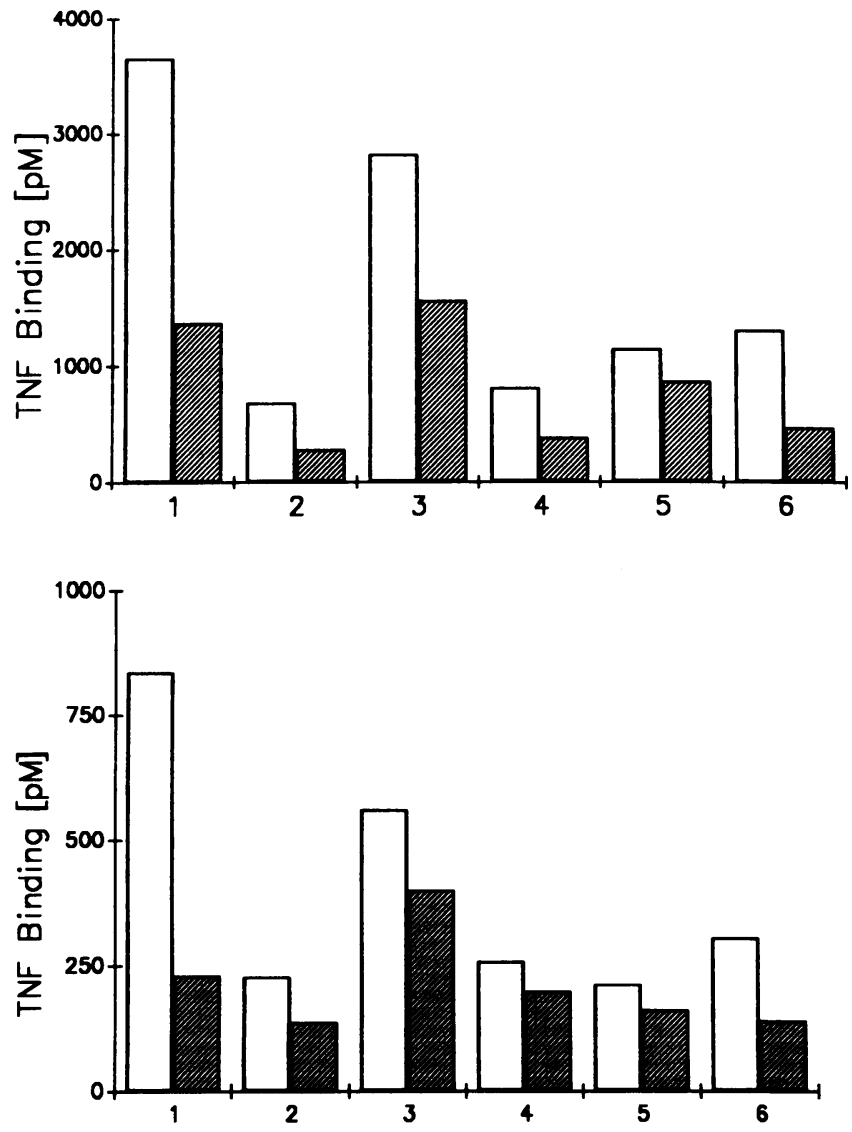

Figure 2. TNFBP in the serum of six HCL patients before (open bars) and after 6 mo of treatment with rhIFN $\alpha$ (stippled bars). Type A (top) and type B TNFBP (bottom) are measured as described in Methods and expressed as TNF binding capacity in picomoles of TNF per liter of serum. Patients 2,4 , and 6 were in complete remission after rhIFN $\alpha$ treatment ( $<5 \%$ hairy cells in a bone marrow core biopsy and improvement in peripheral counts with $\mathrm{Hb}>12 \mathrm{~g} / \mathrm{dl}$, platelets $>100,000 / \mu \mathrm{l}$, neutrophils $>1,500 / \mu \mathrm{l})$, whereas patients 1 , 3 , and 5 were in partial remission ( $>5 \%$ hairy cells in the bone marrow core biopsy but at least a $50 \%$ decrease from baseline, and improvement in peripheral counts) after $\operatorname{rhIFN} \alpha$ treatment.

disease no similar reduction was found. The serum concentration of TNFBP remained constant at a low level for an observation period of $72 \mathrm{wk}$ (data not shown).

\section{Discussion}

We have analyzed the sera of 167 patients with both hematologic and nonhematologic malignancies for the presence of TNFBP. A sandwich type of immunoassays using immobilized anti-TNFR MAb and ${ }^{125}$ I-rhTNF $\alpha$ allowed us to specifically determine types A and B TNFBP that are antigenically equivalent to the 75-kD TNFR (MAb utr-4) and the 55-kD TNFR (MAb htr-20), respectively. A significant increase of the mean TNFBP serum concentration was detected in all patient groups, but the most notable result was the exceptionally high TNFBP concentrations with predominance of type A over type B TNFBP in the sera of most HCL and B-CLL patients. In experimental edotoxinemia in healthy subjects only a maximal fivefold increase of both types A and B TNFBP levels were observed (20). The cellular source of TNFBP in HCL and B-
CLL is presently unknown. However, we observed that levels of TNFBP decreased in HCL during effective rhIFN $\alpha$ therapy, suggesting a correlation of circulating TNFBP with tumor cell load. However, TNFBP serum concentrations were not correlated with clinical staging of HCL and B-CLL $(18,19)$. TNF has been found to be produced by HCL and B-CLL cells $(5,7$, 21) and to stimulate proliferation of $\mathrm{HCL}$ and B-CLL cells in vitro $(5,6)$. It is possible that TNF serves as an autocrine growth factor in both disease states and thus TNFBP may play an important role in the regulation of neoplastic cell growth in $\mathrm{HCL}$ and B-CLL. It is of note, however, that more mature B-cell malignancies such as multiple myeloma failed to exhibit increased type A TNFBP levels.

In most other malignancies elevated serum concentrations of predominantly type B TNFBP with a fairly constant ratio of type $B$ to type A proteins were disclosed. Therefore we assume that the TNFBP in these cases are not produced by the neoplastic cells themselves. It has, for instance, been shown that neutrophiles are a potent source of TNFBP when activated (22). The existence of circulating soluble forms of cytokine receptor proteins applies for a variety of other cytokine receptors as well. In contrast, however, to the soluble IL-2, IL-4, or IL-7 receptors $(23,24)$, soluble TNFR are most likely the products of posttranslational processing of the TNFR molecules (11, 15-17).

Once in systemic circulation, soluble receptor protein fragments such as TNFBP can compete with cell-bound receptors for ligand. They may thus form a pool of scavenger molecules which neutralize highly toxic cytokines such as TNF. More complex functions for soluble receptor fragments are conceivable, if, e.g., the existence of membrane-bound TNF is taken into account. From a practical point of view, combined measurements of TNF and inhibiting TNFBP, rather than that of TNF alone, will provide an additional important parameter of the cytokine status in a given clinical situation.

\section{Acknowledgments}

We thank Drs. Hansruedi Loetscher and Werner Haas for valuable comments during this work and for their critical reading of the manuscript.

This study was supported by the grant from the Dr. Mildred Scheel Foundation to Dr. Herrmann.

\section{References}

1. Old, L. J. 1985. Tumor necrosis factor (TNF). Science (Wash. DC). 230:630.

2. Mestan, J., W. Digel, S. Mittnacht, H. Hillen, D. Blohm, A. Möller, H. Jacobsen, and H. Kirchner. 1986. Antiviral effects of recombinant tumour necrosis factor in vitro. Nature (Lond.). 323:816-817.

3. Tracey, K. J., H. Vlassara, and A. Cerami. 1989. Cachectin/tumour necrosis factor. Lancet. 1122-1126.

4. Beran, M., K. B. McCredie, M. J. Keating, and J. U. Gutterman. 1988. Antileukemic effect of recombinant tumor necrosis factor $\alpha$ in vitro and its modulation by $\alpha$ and $\gamma$ interferons. Blood. 72:728-738.

5. Cordingley, F. T., A. V. Hoffbrand, H. E. Heslop, M. Turner, A. Bianchi, J. E. Reittie, A. Vyakarnam, A. Meager, and M. K. Brenner. 1988. Tumour necrosis factor as an autocrine tumour growth factor for chronic B-cell malignancies. Lancet. $i: 969-971$.

6. Digel, W., M. Stefanic, W. Schoeniger, C. Buck, An. Raghavachar, N. Frickhofen, H. Heimpel, and F. Porzsolt. 1989. Tumor necrosis factor induces proliferation of neoplastic B-cells from chronic lymphocytic leukemia. Blood. 73:1242-1246.

7. Lindemann, A., W. D. Ludwig, W. Oster, R. Mertelsmann, and F. Herrmann. 1989. High level secretion of tumor necrosis factor-alpha contributes to hematopoietic failure in hairy cell leukemia. Blood. 73:880-884. 
8. Brach, M. A., H. J. Gruss, Y. Asano, W. D. Ludwig, R. Mertelsmann, and F. Herrmann. 1991. Synergy of interleukin-3 and tumor necrosis factor (TNF)- $a$ in stimulating clonal growth of acute myelogenous leukemia blasts is the result of induction of secondary hematopoietic cytokines by TNF- $\alpha$. Canc. Res. In press.

9. Hoang, T., B. Levy, N. Quetto, A. Haman, and J. C. Rodriguez-Cimadevilla. 1989. Tumor necrosis factor $\alpha$ stimulates the growth of clonogenic cells of acute myeloblastic leukemia in synergy with granulocyte-macrophage colonystimulating factor. J. Exp. Med. 170:15-24.

10. Salem, M., R. Delwel, I. Touw, L. A. Mahmond, E. M. Elbasousy, and B. Löwenberg. 1990. Modulation of CSF-dependent growth of acute myeloid leukemia by tumor necrosis factor. Leukemia. 4:37-41.

11. Loetscher, H., Y. E. Pan, H. Lahm, R. Gentz, M. Brockhaus, H. Tabuchi, and $\mathrm{W}$. Lesslauer. 1990. Molecular cloning and expression of the $55 \mathrm{kd}$ tumor necrosis factor receptor. Cell. 61:351-359.

12. Schall, T. J., M. Lewis, K. J. Koller, A. Lee, G. C. Rice, G. H. W. Wong, T. Gatanaga, G. A. Granger, R. Lentz, H. Raab, et al. 1990. Molecular cloning and expression of a receptor for human tumor necrosis factor. Cell. 61:361-370.

13. Smith, C. A., T. Davis, D. Anderson, L. Solam, M. P. Beckmann, R. Jerzy, S. K. Dower, S. D. Cosman, and R. G. Goodwin. 1990. A receptor for tumor necrosis factor defines an unusual family of cellular and viral proteins. Science (Wash. DC). 248:1019-1023.

14. Brockhaus, M., H. J. Schoenfeld, E. J. Schlaeger, W. Hunziger, W. Lesslauer, and H. Loetscher. 1990. Identification of two types of tumour necrosis factor receptors on human cell lines by monoclonal antibodies. Proc. Natl. Acad. Sci. USA. 87:3127-3131.

15. Dembic, Z., H. Loetscher, U. Gubler, Y. Pan, H. Lahm, R. Gentz, M Brockhaus, and W. Lesslauer. 1990. Two human TNF receptors have similar extracellular, but distinct intracellular domain sequences. Cytokine. 2:231-237.

16. Engelmann, H., D. Novick, and D. Wallach. 1990b. Two tumor necrosis binding proteins purified from human urine: evidence for immunological crossreactivity with cell surface tumor necrosis factor receptors. J. Biol. Chem. 265:1531-1536.

17. Seckinger, P., J. Zhang, B. Hauptmann, and J. Dayer. 1990. Characterization of a tumor necrosis factor $\alpha$ inhibitor: Evidence for immunological crossreactivity with TNF receptor. Proc. Natl. Acad. Sci. USA. 87:5188-5192.

18. Jansen, J., and J. Hermans. 1982. Clinical staging system for hairy-cell leukemia. Blood. 60:571-576.

19. Rai, K. R., A. Sawitsky, E. P. Cronkite, A. D. Chanana, R. N. Levy, and B. S. Pasternack. 1975. Clinical staging of chronic lymphocytic leukemia. Blood. 46:219-234

20. Spinas, G. A., U. Keller, and M. Brockhaus. 1992. Increased plasma levels of soluble receptors for tumor necrosis factor (sTNF) in experimental endotoxinemia: comparison with circulating TNF. J. Clin. Invest. In press.

21. Foa, R., M. Massaia, S. Cardona, A. G. Tos, A. Bianchi, C. Attisano, A. Guarini, P. F. Di Celle, and M. T. Fierro. 1990. Production of tumour necrosis factor-alpha by B-cell chronic lymphocytic leukemia cells: a possible regulatory role of TNF in the progression of the disease. Blood. 76:393-400.

22. Porteu, F., and C. Nathan. 1990. Shedding of tumour necrosis factor receptors by activated human neutrophils. J. Exp. Med. 172:599-607.

23. Mosley, B., M. P. Beckmann, C. J. March, R. L. Idzerda, S. D. Gimpel, T VandenBos, D. Friend, A. Alpert, D. Anderson, J. Jackson, et al. 1989. The murine interleukin-4 receptor: molecular cloning and characterization of secreted and membrane bound forms. Cell. 59:335-348.

24. Goodwin, R. G., D. Friend, S. Ziegler, R. Jerzy, B. A. Falk, S. Gimpel, D. Cosman, S. K. Dower, C. J. March, A. E. Namen, et al. 1990. Cloning of the human and murine interleukin-7 receptors: demonstration of a soluble form and homology to a new receptor superfamily. Cell. 60:941-951. 